\title{
Interpersonal Metaphor in R. S. Regin Silvest and Malini Ganapathy's Anthology of Covid-19 Poems
}

\author{
Sri Rezeki ${ }^{1, *}$ Amrin Saragih ${ }^{2}$ Winda Setiasari ${ }^{3}$
}

\author{
${ }^{1}$ Universitas Negeri Medan, Indonesia \\ ${ }^{2}$ Universitas Negeri Medan, Indonesia \\ ${ }^{3}$ Universitas Negeri Medan, Indonesia \\ *Corresponding author. Email: kikirizki800@gmail.com
}

\begin{abstract}
The aim of the study was to find out the types of Interpersonal Metaphor in R. S. Regin Silvest and Malini Ganapathy's Anthology of Covid-19 Poems. This study was conducted by applying the qualitative method. The data were collected by applying document data collection, the study was analyzed by using Halliday and Mattheissen theory, to identify the types of Interpersonal Metaphor, Halliday and Mattheissen divided the types of Interpersonal Metaphor into two namely, Interpersonal Metaphor of Mood and Interpersonal Metaphor of Modality. The result shows that there are sixty seven Interpersonal Metaphor found in the Covid-19 Poems, they are forty one Interpersonal Metaphor of Mood (61\%) and twenty seven Interpersonal Metaphor of Modality (39\%).
\end{abstract}

Keywords: Interpersonal Metaphor, Poems, Covid-19.

\section{INTRODUCTION}

In 2019, a disease epidemic struck the human race in Wuhan, China, called COVID-19 (Corona Virus Disease 19). On January 30, 2020, WHO announced the Chinese COVID-19 outbreak Public Health Crisis of International attention, causing great danger to countries with weak health systems (2020) [1] The Covid-19 Pandemic has a significant impact on human interactions; as a result, people all over the world must stay at home and make a social distancing to block the transmission of the virus. In this situation human beings find another way to do their job and communicate with each other and, they work by the online platform.

Because of the Covid-19 Pandemic, people communicate on the online platform, and some of them declare and show their feeling in the Literary work, one of the form literary work is a poem. A poem is a term used to express an experience that provides at least four dimensions [2]. It must be aimed at the whole person, not just our understanding and knowledge if it is to convey the experience. It must encompass not only our intellect but also our senses, emotions, and creativity. Poetry adds a sensual dimension, an emotive dimension, and an inventive dimension to the creative arena. Some people communicate their experience in facing the Covid-19 situation nowadays.
Poem explores facets of human interaction and communication during the COVID-19 pandemic of 2020. The investigation is based on the desire for ordinary experiences and the fear of contamination through a collection of poems [3]. In 2020, R. S. Regin Silvest and Malini Ganapathy published Covid-19 Pandemic Poems, an anthology book that collected poetry from around the world. This collection of poems documents people's reactions to the Pandemic Covid-19 situation around the world [4]. People write poems to express their feelings, opinions, fears, and suggestions about the Corona Virus attack.

In this pandemic Covid-19 situation, people need to communicate with each other because communication is the effective way to deliver our idea, feeling, and thought, and also our fear of the virus. People communicate with each other through speech, we can refer to the system of communication that they use as a code, which we can also refer to as a language [5]. It is unmistakably mentioned that we need a language in everything we do and that we live in a global language. Language distinguishes humans from other species more than any other attribute. To understand our humanity, we must first comprehend the essence of language, which is what makes us human, and we may refer to language as the source of human life and strength [6].

Because language is a human being's power, we must use it to provide support and spread a positive message, 
which we do through communication, communication within communities, which is mostly done through both written and spoken communications. Discourse analysis involves the discussion of language relationships and the intercourse in which they are used. By recognizing the connection between the linguistic structure and the functions, discourse analysis focused on both spoken and written texts. Discourse analysis focuses on the language options that people use to reach their social purposes, and cultural ideologies obtained in the discourse play an important role in their analysis [7]. Interpersonal metaphor is discussed in discourse analysis. Interpersonal metaphor is an incongruent expression that involves the transference of clause types in terms of mood and modality. Based on the explanation above this study will discuss the Interpersonal metaphor in Anthology Covid19 poems compiled by R. S. Regin Silvest and Malini Ganapathy.

\section{LITERATURE REVIEW}

\subsection{Interpersonal Metaphor}

Interpersonal metaphor which includes metaphor of mood and metaphor of modality. Interpersonal metaphors of modality are realized when modal meanings are expressed outside the clause, while congruently, modal meanings are conveyed within the clause. For example, to express a high likelihood of being true (e.g. this must be true), modal meanings can be expressed outside the clause (e.g. it is certain that this is true). In the same way, interpersonal metaphors of mood are realized when mood meanings are not expressed within the clause. For example, congruently, a command functions as a warning (e.g. Don't go there!). Metaphorically, a statement can be used to give a warning I wouldn't go there if I were you [8].

\subsubsection{Interpersonal Metaphor of Mood}

Metaphor of mood is the exchanging system giving or demanding information or good and services, which determines the four basic speech function of statement, question, offer, and command [8]. The basic speech function of statement, question and command are congruently or commonly realized by the declarative, interrogative and imperative mood respectively. The speech function of offers does not have an unmarked or a common realization. In other words, the uncommon or uncongruent realization of basic speech function deals with metaphorical in metaphor of mood.

\subsubsection{Interpersonal Metaphor of Modality}

Modality as the speaker's judgments of probabilities, or the obligation involved in what she/he is saying.
Modality can be either modalization (the indicative type implying the degrees of probability and usuality) or modulation (the imperative type implying the degrees of obligation and inclination). Modalization is the expression of the speaker's opinion and modulation is the exchange of the goods- $\&$-services or information between speaker and hearer.

\subsection{Poetry}

Poetry might be defined as a kind of a language that says more and says it more intensely than ordinary language does. It means that poetry uses certain language: it is not ordinary language that we use every day. Because the ordinary language has function to communication but, poetry is not primarily to communicate only. This exist to bring us sense and perception of life with the experience before, to know the experience of other, and to understand our own experience better. Poetry is the capture of the picture, a song, or flair, in a deliberate prism of words. In a poem, a human being expresses his unique and personal experience of his world and his life. The poet imaginatively explores and orders such experience. Poetry like a prose is a form of discourse whose instrument is language. Its function is to communicate, and its must never allow its emotional content to obliterate its message [2].

\subsection{Pandemic Covid-19}

In 2020, another ferociously maleficent pandemic deeply marks humanity, closing frontiers and pushing millions and millions of people to confine themselves, restricting their freedom, distancing them from their loved ones and limiting their potential to the walls of their houses. At similar times marked by restriction and loss, grief and sorrow as well as aspiration and hope, art stands as men only salvation and solace. The impositions of travel restrictions, social distancing and self-quarantining, regardless of their success in limiting the pandemic, deeply affected Man and pushed them to consider 'life and death,' 'love and passion,' and 'meaning and construction.' While newsrooms gauges with fear and agony, the rooms of our poets spread hope, life, and creation in the face of death, pain, and loss. Bearing in mind William Wordsworth's words that poetry is the "spontaneous overflow of strong and powerful emotions", the COVID 19 VOL III poetry collection 50 poems in ENGLISH steps in as a healing force at the time of collective grief and pain [4].

\section{RESEARCH METHOD}

The qualitative method will be used to conduct this study. Qualitative research is a method for investigating and understanding the meaning that individuals or groups 
ascribe to social or human problems [9]. According to the theories discussed above, this study is classified as qualitative research, and the purpose of this study was to discover the Interpersonal Metaphor in Covid19 poems.

\section{RESULT AND DISCUSSION}

\subsection{Types of Interpersonal Metaphor of Mood}

Based on the result of the data analysis, there are forty one interpersonal metaphor of mood found in Poems of Covid-19, and in analyzing the Interpersonal metaphor of mood in the Covid-19 poems all the data were classified into clauses in order to get the ideas about the use of interpersonal metaphor in poems of Covid-19.

Table 4.1. Types of Interpersonal Metaphor of Mood

\begin{tabular}{|l|c|c|}
\hline $\begin{array}{l}\text { Types of Interpersonal } \\
\text { Metaphor of Mood }\end{array}$ & The Number & Percentage \\
\hline $\begin{array}{l}\text { Statement in } \\
\text { Interrogative Mood }\end{array}$ & 5 & $12 \%$ \\
\hline $\begin{array}{l}\text { Statement in } \\
\text { Imperative Mood }\end{array}$ & 18 & $10 \%$ \\
\hline $\begin{array}{l}\text { Question in } \\
\text { Declarative Mood }\end{array}$ & 1 & $24 \%$ \\
\hline $\begin{array}{l}\text { Question in } \\
\text { Imperative Mood }\end{array}$ & 13 & $32 \%$ \\
\hline $\begin{array}{l}\text { Command in } \\
\text { Declarative Mood }\end{array}$ & 41 & $100 \%$ \\
\hline Total & & \\
\hline
\end{tabular}

Based on the table, the data showed that the Poems of Covid-19 used interpersonal metaphor of mood realized in unmark form, there are four unmark form namely Statement in Interrogative Mood (12\%), Statement in Imperative Mood (10 \%), Question in Declarative Mood (44\%), Question in Imperative Mood (2\%), and Command in Declarative Mood (32\%), and the dominant form was Question in Declarative Mood.

\subsubsection{Statement in Interrogative Mood}

Basically the congruent realization of statement is declarative mood. Therefore, it is recorded by an interrogative Mood then it becomes a metaphorical indication. The following data shown the process of Interpersonal indication.

Data:

They will return with lesser hue next spring Will those thousand show life again?

In this poem the author represents the death of thousands of people like the fall of cherry blossoms, based on the context of Will those thousands show life again? clause is indicated as Statement speech function and commonly Speech function is realized by declarative mood because the clause wants to convey that thousands of dead people will not live again, but the clause coded by Interrogative Mood and it becomes metaphorical expression.

\subsubsection{Statement in Imperative Mood}

Basically the congruent realization of statement is declarative mood. Therefore, it is recorded by an Imperative Mood then it becomes a metaphorical indication. The following data shown the process of Interpersonal indication.

Data:

It's a battle for peace!

People were forced to stay locked inside, not passing beyond theirs doors

But some were forced to leave the place they called home.

In this poem the author represents the death of thousands of people like a battle, Interpersonal metaphor coded in the clause of it's a battle for peace The clause indicated as Statement speech function and the purpose is want to tell the people that Covid19 Pandemic is the battle, but in this clause the author provide the clause as the Imperative mood and in Command speech function because of that the clause is Interpersonal metaphor of mood.

\subsubsection{Question in Declarative Mood}

Basically the congruent realization of question is interrogative mood. Therefore, it is recorded by a declarative Mood then it becomes a metaphorical indication. The following data shown the process of Interpersonal indication.

\section{Data: \\ I am waiting on Google Meet, all night through Thinking how the lesson would glue}

Interpersonal metaphor coded in the clause of $\boldsymbol{I}$ am waiting on Google Meet, all night through Thinking how the lesson would glue the clause indicated as Question speech function, the clause means asking everyone about how studying in an online class can understand the lesson well. But in this clause the author provide the clause as the declarative mood not in interrogative form because of that the clause indicate as Interpersonal metaphor of mood.

\subsubsection{Question in Imperative Mood}

Basically the congruent realization of question is interrogative mood. Therefore, it is recorded by an Imperative Mood then it becomes a metaphorical 
indication. The following data shown the process of Interpersonal indication.

\section{Data:}

The Government itself gave permission to you. So, why can't you stay with us!

Interpersonal metaphor coded in the clause of The Government itself gave permission to you. So, why can't you stay with us! The clause indicated as Question speech function, the clause means hoping and asking Corona can coexist with human life without destroying it. But in this clause the author provide the clause as the imperative mood not in interrogative form because of that the clause indicate as Interpersonal metaphor of mood.

\subsubsection{Command in Declarative Mood}

Basically the congruent realization of command is imperative mood. Therefore, it is recorded by a declarative Mood then it becomes a metaphorical indication. The following data shown the process of Interpersonal indication.

\section{Data:}

WHO, from time to time, declares to maintain social-distancing

As if a sneeze or a cough in public or chilling in hordes can snatch the lives.

In this poem the author represents the death of thousands of people like a demon and terrorize, Interpersonal metaphor coded in the clause, it is indicated as command speech function and the purpose is want to command and suggest the people do social distancing to prevent the spread of the Covid19, but in this clause the author provide the clause as the declarative mood not imperative mood and because of that the clause is Interpersonal metaphor.

\subsection{Types of Interpersonal Metaphor of Modality}

Based on the result of the data analysis, there are twenty seven interpersonal metaphor of modality found in Poems of Covid-19, and in analyzing the Interpersonal metaphor of modality in the Covid-19 poems all the data were classified into clauses in order to get the ideas about the use of interpersonal metaphor in poems of Covid-19.

Table 4.2. Types of Interpersonal Metaphor of Modality

\begin{tabular}{|l|c|c|}
\hline $\begin{array}{l}\text { Types of Interpersonal } \\
\text { Metaphor of Modality }\end{array}$ & The Number & Percentage \\
\hline Modalization & 14 & $54 \%$ \\
\hline Modulation & 12 & $46 \%$ \\
\hline Total & 26 & $100 \%$ \\
\hline
\end{tabular}

Based on the table, the data showed that the Poems of Covid-19 used interpersonal metaphor of Modality realized in Modalization (52 \%) and Modulation (48\%) Congruently modality coded by Modals. However, modality can be coded by a number of resources, one of the metaphorical ways to code modality is by using Mental process verb (reckon, think believe, etc) and it is become Interpersonal Metaphor of Modality [10].

\subsubsection{Modalization}

Modalization is the expression of the speaker's attitude towards what she/he is saying, it is the way the speaker gets into the text, express a judgment about the certainty, likehood or frequency of something happening or being.

The following data shown the process of Interpersonal indication.

Data 1:

With his great scientific findings he tried to do many things

He thinks the world is at his fingertips

But corona shattered and smashed his dreams

In the example above "He thinks" is used as metaphorical realization of modality because the clause using mental process verb. The interpersonal of modality in this sentence express that human thinks has the biggest power in this word then he is arrogant but Corona shatter the human's arrogances.

\subsubsection{Modulation}

Modulation is a way for speakers to express their judgments or attitudes about actions and events. As a part of interpersonal realization, modulation always deals with demanding, direction, advice, permission, undertaking, or capability.

The following data shown the process of Interpersonal indication.

Data I:

We disrespect this earth, and we never feel ashamed

I hope now everyone realize that this is the Mother Nature revenge.

The data above "I hope" is used as the metaphorical realization of modality because the clause uses mental process verb. The interpersonal of modality in this sentence expresses the desire and wish that humans should respect and protect the Earth from damage caused by human greed.

\section{CONCLUSION}

Based on the result of the data analysis, there are forty one interpersonal metaphor of mood found in Poems of Covid-19, and in analyzing the Interpersonal metaphor of 
mood in the Covid-19 poems all the data were classified into clauses in order to get the ideas about the use of interpersonal metaphor in poems of Covid-19. Statement in Interrogative Mood (12\%), Statement in Imperative Mood (10\%), Question in Declarative Mood (44\%), Question in Imperative Mood (2\%), Command in Declarative Mood (32\%). The Poems of Covid-19 used interpersonal metaphor of Modality realized in Modalization (52 \%) and Modulation (48\%), there are twenty seven interpersonal metaphor of mood found in Poems of Covid-19.

\section{AUTHORS' CONTRIBUTIONS}

The authors confirm contribution to the paper as follow: SR conducted the study conception and design, data collection, analysis and interpretation of results, AS and WS conducted draft manuscript preparation and reviewing the article before submission not only for spelling and grammar but also for its intellectual content and all the authors reviewed the results and approved the final version of the manuscript.

\section{ACKNOWLEDGMENTS}

This paper and the research behind it would not have been possible without the exceptional support of my supervisors, Prof. Amrin Saragih, M.A., Ph.D. and Dr. Winda Setiasari, S.S, M.Hum., Ph.D.

\section{REFERENCES}

[1] World Health Organization. (2020). Situation Report. New York: WHO.

[2] Perrine, L., and Thomas. (1992). Sound and sense: An Introduction to Poetry $8^{\text {th }}$ Edition. Harcourt Brace Collage Publisher

[3] Pelias, R. J. (2020). Contact and the 2020 Pandemic: A Poetic Autoethnography. International Review of Qualitative Research. 00(0), 1-7.

[4] Silvest, R. S., and Ganapathy, M. (2020). Covid19 Pandemic Covid-19. India: Cape Comorin Pubhliser.

[5] Wardaugh, R., and Fuller, M. J. (2015). An Introduction to Sociolinguistics $\left(7^{\text {th }}\right.$ ed). UK: Blackwell Publishing.

[6] Fromkin, V., Rodman, R., Hyams, N. (2003). An Introduction to Language ( $7^{\text {th }}$ ed). US: Wadsworth.

[7] Alsoraihi, M. H. (2019). Bridging the Gap Between Discourse Analysis and Language Classroom Practice. Journal of English Language Teaching. 12(8). 74-88.
[8] Halliday, M. A. K. and Christian M. I. M Matthiessen. (2004). An Introduction to Functional Grammar. London:Edwar Arnold

[9] Creswell, J. W., and Creswell, J. D. (2018). Research Design: Qualitative, Quantitative and Mix Methods Approaches (5 $5^{\text {th }}$ ed). USA: SAGE Publications, Inc.

[10] Saragih, A. (2014). Discourse Analysis: A Study on Discourse Based on Systemic Functional Linguistic Theory. Medan: English Applied Linguistic Study Program Postgraduate Studies, UNIMED. 